\title{
Using gender responsive collaborative learning strategy to improve students' achievement and attitude towards learning science in virtual and hands-on laboratory environment
}

\author{
Jeremiah Nosakhare Akhigbe ${ }^{1}$ and Adeola Eunice Adeyemi ${ }^{2}$ \\ ${ }^{1}$ Department of Science and Technology, Faculty of Education, University of Lagos, Nigeria (ORCID: 0000-0001-7410-6279) \\ ${ }^{2}$ Department of Science and Technology, Faculty of Education, University of Lagos, Nigeria (ORCID: 0000-0002-5753-1975)
}

\begin{abstract}
One way of ensuring gender equality in science education is by mainstreaming gender components into the pedagogical delivery of science instruction. Thus, the researchers in this study designed a Gender Responsive Collaborative Learning Strategy (GR-CLS) based on Universal Design for Learning (UDL) principles. The effectiveness of this instructional paradigm on students' achievement and attitude was determined in a mixed factorial quasi-experimental research design study conducted in a virtual and hands-on laboratory learning environment. Multistage sampling technique was used to select a total sample of 218 secondary school students from same sex and mixed sex schools. The six hypotheses formulated in the study were tested using Means and Analysis of Covariance (ANCOVA). Empirical findings revealed a significant difference in the mean achievement and attitude scores of both male and female students who were exposed to GR-CLS under virtual and hands-on laboratory environment respectively compared to those who were not exposed to GR-CLS. These results indicate that GR-CLS is an effective pedagogical strategy for improving students' achievement and attitude regardless of gender. Nevertheless, it was discovered that GR-CLS leads to a significant improvement in the achievement of students from same sex schools over mixed sex schools. The study, therefore, recommends the adoption of GR-CLS by science teachers in the planning and implementation of science lessons to create equal opportunities for both male and female students to benefit maximally from learning activities carried out in the laboratory.
\end{abstract}

Keywords: Gender equality; Collaborative learning; Virtual laboratory; Achievement; Attitude

Article History: Submitted 18 May 2020; Revised 15 July 2020; Published online 14 October 2020

\section{Introduction}

Although progressive improvements are being made towards attaining gender parity, gender inequality still prevails in the educational attainment of males and females at all levels in developing countries (United Nations Educational, Scientific and Cultural Organization [UNESCO], 2012). Specifically, Sub-Sahara Africa ranks the least among nations where gender

Address of Corresponding Author

Jeremiah Nosakhare Akhigbe, PhD, Department of Science and Technology, Faculty of Education, University of Lagos, Eyo Ita Cres, Yaba, Lagos, Nigeria.

$\nabla$ jakhigbe@unilag.edu.ng

How to cite: Akhigbe, J. N., \& Adeyemi, A. E. (2020). Using gender responsive collaborative learning strategy to improve students' achievement and attitude towards learning science in virtual and hands-on laboratory environment. Journal of Pedagogical Research, 4(3), 241-261. 
equality in education has been achieved (United States Agency for International Development [USAID], 2015). Gender has a strong link with the performance of students in Science, Technology, Engineering, and Mathematics (STEM). A number of factors have also been attributed to be responsible for the underachievement of females in STEM. The gender stereotyping of science as masculine and the cultural belief that females do not have the full cognitive capacity for learning science are some of the prevalent factors that contribute to gender gaps in the achievement of males and females in science (Ekine, 2013; Scantlebury \& Baker, 2007). Furthermore, gender bias is often manifested in science curricula, instruction, and assessment (Miske, 2013). For instance, gender inequality still plays out as students get involved in laboratory activities. Female students are often sidelined and dominated by the males during laboratory activities because the males in a particular collaborative learning group take up leadership roles and manipulate the use of equipment while the girls in the group are left to take up passive roles (Ekine, 2013; Sempala, 2005). This classroom practice dissuades girls in their pursuance of science, and in most cases, impedes on their self-esteem and attitude towards science (Baker, 2013). The virtual laboratory has, however, been identified as an effective pedagogical tool that can be incorporated into science instruction to enhance females' participation and achievement in science (Gambari, Kawu, \& Falode, 2018), and in the visualization of abstract science concepts (Zacharia, 2015). Nevertheless, closing the gender gaps in science achievement should not only be a priority, but criteria must also be set to devise permanent ways of addressing these anomalies in order to improve girls' participation in science. This can be achieved by mainstreaming gender components into science education activities and teachers' pedagogical delivery (UNESCO, 2017). By this, the study advocates for gender responsive pedagogies that accommodate the need, interest, and experience of students irrespective of their gender to create an enabling environment for female students to benefit maximally from science laboratory activities. Consequently, the researchers in this study designed a gender responsive collaborative learning strategy, and thereafter, tested the impact of this instructional paradigm on students' achievement and attitude towards learning in a virtual laboratory and hands-on laboratory environment.

\subsection{Literature Review}

One of the main features of science which distinguishes it from other subjects is its' empirical nature that involves the verification of facts and findings through experimentation. The laboratories, thus, serve as the workstation for conducting experiments in science. The laboratory fosters learning experiences by providing students with opportunities to interact with equipment and materials or gather secondary data based on observation and understanding of the natural world (Hofstein \& Kind, 2012). The laboratory also plays a critical role in students' formation of science concepts because it provides avenue for students to acquire practical and hands-on skills for learning abstract concepts. Nevertheless, the typical Nigerian secondary school is confronted with the challenges of inadequate laboratory supplies and equipment (Adejoh \& Ityokyaa, 2009). Because of dearth in laboratory resources, laboratory practices, which ideally should accompany every learning module in the Nigerian science curriculum, are rarely organized for students thereby contributing to high failure rate in science (Olorundare, 2014; West African Examinations Council [WAEC], 2015). Thus, there is an urgent need for Nigeria schools to take a paradigm shift from the traditional time-tested teacher-centered demonstration towards laboratory practices that provide students with opportunities to demonstrate and, visualize or verify information via the use innovative technologies (Gambari, Obielodan, \& Kawu, 2017). The adoption of virtual laboratory in Nigerian secondary schools thus presents itself as an alternative to the traditional physical laboratory.

The use of virtual laboratory in science instruction is gaining more ground and becoming a trend in education. This is necessitated by the rapid evolution of information and communication technology (ICT), and the massive application of artificial intelligence in the design of effective instructional tools that can be deployed for teaching complex science topics (Batateen, 2011). 
Virtual laboratory uses computerized models to provide highly interactive virtual reality simulations of laboratory exercises. It is a software designed to simulate the physical laboratorylearning environment and provides students with interactive interface for conducting computercontrolled experiments (Babateen, 2011). Virtual laboratory is as effective as the physical laboratory based on argument put forward by researchers in the field (Gambari, Fagbemi, Falode, \& Idris, 2013; Pyatt \& Sims, 2012; Talti \& Ayas, 2012). The affordance of virtual laboratory simulations makes it possible to conduct experiments repeatedly at no additional cost (Toth, 2016). Virtual laboratory also enables learning irrespective of times, space and resources (Brinson, 2015; Parker \& Loudon, 2012; Pyatt \& Sims, 2012; Rajendran, Veilamuthu, \& Divya, 2010). Thus, providing opportunities for students to work independently or in collaborative small groups regardless of the size of a schools' physical laboratory, equipment, and consumables is crucial (Herga, Cagran, \& Dinevski, 2016).

Virtual laboratory can be introduced into the classroom as a precursor to hands-on experiments conducted in the physical laboratory in other to create a smooth blend of both learning environments (Adegoke \& Chukwunenye, 2013; Bortnik, Stozhko, Pervukhina, Tchernysheva, \& Belysheva, 2017; Omilani, Ochanya, \& Aminu, 2018). A review of empirical research findings on virtual laboratory document results that gives an exposition into the significant role of virtual laboratory in improving students' achievement (Bajpai \& Kumar, 2015; Omilana et al., 2018); attitude (Apkan \& Strayer, 2010; Gambari et al., 2013; Tuysuz, 2010), and engagement (Bortnik et al., 2017). Nevertheless, findings from Ambusaidi, Al-Musawi, Al-Balushi and Al-Balushi (2017) revealed that virtual laboratory do not have any significant improvement on the achievement and attitude of students towards science. In another dimension, Darrah, Humbert, Finstein, Simon and Hopkins (2014), Mcqueen (2017), Pyatt and Sims (2012), and Zacharia and Olympiou (2011) document findings which equate the effectiveness of virtual laboratory to the physical laboratory.

Virtual laboratory experiments can be implemented in a collaborative learning environment by providing opportunity for students to work together on challenging tasks (Tuysuz, 2010). Findings from the studies conducted by Gambari et al. (2017) and Gambari et al. (2018) suggest that students' exposure to virtual laboratory experiments in a collaborative setting results into significant improvements on their performance in science when compared to students who were exposed to similar virtual laboratory experiments in an individualized setting. This finding reaffirms the important role of students' collaboration in science practices. However, researchers do not hold similar opinion when it comes to the homogenous and heterogenous grouping of students by gender in a collaborative learning environment. For instance, Shi, He, Wang and Huan (2015) reported that same sex grouping of students in a collaborative learning environment favours all female collaborative learning group than all male collaborative learning group. Likewise, Tsai (2012) posited that female-female interaction is stronger than male- male or malefemale interactions respectively. Furthermore, Gambari et al. (2018) expounded that exposure of students to virtual laboratory experiments in a collaborative setting significantly improves the performance of females in homogenous collaborative learning group who outperformed the females in the heterogenous collaborative learning group. This finding corroborates with the findings of Bennett, Hogarth, Lubben, Campbell and Robinson (2010) who revealed that all girls collaborative learning group was more effective than mixed sex collaborative learning group. These findings on gender suggest that female students find it more comfortable to work with their fellow female students on academic tasks as against cross gender interactions.

Virtual laboratory is a computer-based technology that may increase the possibilities for interactivity and improvements in students' performance if considered. Unfortunately, Nigeria is yet to fully embrace the use of virtual laboratory in teaching science at the secondary school level (Gambari et al., 2013). In addition, there are only a few research reports on the effectiveness of virtual laboratory on students' learning outcomes in biology. The current study, therefore, presents a critical gender lens study of students' learning outcomes in a virtual and hands-on laboratory learning environment. 


\subsection{The Aim}

This study aims to:

a. develop a Gender Responsive Collaborative Learning Strategy (GR-CLS).

b. determine the impact of GR-CLS on students' achievement in biology lesson when implemented under virtual and hands-on laboratory learning environment.

c. determine the impact of GR-CLS on students' attitude towards biology in a virtual and handon laboratory learning environment.

d. determine if gender will moderate the effect of GR-CLS on students' achievement in virtual and hand-on laboratory experiments.

e. determine the influence of GR-CLS on males and female students' attitude in a virtual and hand-on laboratory experiments.

f. determine the impact of GR-CLS on students' achievement based on homogenous and heterogenous gender school type.

g. determine the impact of GR-CLS on students' attitude based on homogenous and heterogenous gender school type.

\subsection{The Design of Gender Responsive Collaborative Learning Strategy}

The Gender Responsive Collaborative Learning Strategy (GR-CLS) implemented in the study was designed based on a critical review of previous literature on gender inclusive pedagogy and collaborative models for learning respectively as highlighted in the Table 1 . The GR-CLS framework in Figure 1 draws on the fact that collaborative models for teaching and learning provide students with maximum opportunities for interaction, discussion and cooperation when performing a task to solve a problem or to create a product (Vasiliou \& Economides, 2007).

Table 1

Literature validation of Gender Responsive Collaborative Learning Strategy (GR-CLS)

Insights from Literature on Gender Inclusive Pedagogy

- Encourage collaborative group work and interaction: Baker (2013); Chadwell (2010); Gambari et al. (2017); Hausler and Hoffman (2002); Parker and Rennie (2002); Udeani (2012).

- Use student centred strategies in classroom instruction: Baker (2013); Chadwell (2010); Gurian, Stevens and Daniel (2009); Udeani (2012).

- Foster positive teacher-student relationship: Hubbard and Datnow (2005).

- Provide opportunities for metacognitive reflection and Journaling in the classroom: Gurian et al. (2009); Udeani (2012).

- Tailor instruction to the need and interest of different groups: Gurian et al. (2009); Polcuch (2016).

- Separate students into homogenous learning groups based on their gender: Chadwell (2010); Bennett et al. (2010); Gambari et al. (2018); Parker and Rennie (2002); Stotsky (2012).

- Use gender specific instructional approach: Chadwell (2010); Dickey (2014); Martino and Kehler (2006); Mulholland, Hassan and Kaminski (2004); Gurian et al. (2009).

- Encourage girls' participation in learning task and hands on activities: Baker (2013); Kahle and Meece (1994); Udeani (2012).

- Encourage girls to ask questions and take risk: Chadwell (2010).

- Encourage girls to take up leadership role: Gurian et at (2009).

- Incorporate ICT into instruction to improve girls' participation: Baker (2013); Udeani (2012).

- Use gender neutral language, illustrations and textbooks: Elgar (2004); Miske (2013), Udeani (2012).

- Adopt story-telling and games to enhance girls' interests in science: Burman, Bitan and Booth (2008); Ekine (2013); Miske (2013); Olsen and Gross (2013); Wang, Eccles and Kenny (2013).

- Provide mentorship and bring role models into the classroom: Andre (2011); Hubbard et al. (2005); Nhundu (2007).

- Groom teachers on the use of gender inclusive pedagogies: Ekine (2013); Mackinnon (2000); Miske (2013).

- Plan and implement STEM initiative programmes: Ekine (2013). 
Insights from Literature on Collaborative Models for Learning

- Engage students in challenging tasks and problem-solving activities: Astin (1985); Bonwell and Eison (1991); Brown, Collins and Duguid (1989).

- Cultivate team work, cooperation and leadership among students: MacGregor (1990); Smith and MacGregor (1992).

- Encourage individual and group accountability through task sharing and role distribution: Deutsch (1976); Lewin (1935); Smith and MacGregor (1992).

- Allow student share and present their thought-out ideas in pairs and in small groups: Cerbin (2010).

- Students take turns as tutee and tutor when working on group task: Cerbin (2010); Smith and MacGregor (1992).

- Provide avenue for students' co-constriction and documentation of ideas in a group writing assignment: Cerbin (2010); Smith and MacGregor (1992).

- Allow students to pair up and alternate role between thinking aloud to solve a problem and being the listener: Cerbin (2010).

- Create students learning communities: Cerbin (2010); Gabelmick, MacGregor, Matthew, and Smith (1990).

- Incorporate activities that allow students analyse, classify and organize subject matter via their work in small groups: Cerbin (2010).

- Provide sufficient guide and scaffold for students' collaborative work: Cerbin (2010).

The principles of Universal Design for Learning (UDL) was also applied in the design of the GR-CLS to guide the instructional practices of teachers and students in the gender inclusive classroom learning environment. UDL is an instructional paradigm and an approach to teaching and learning that carters for diverse groups of learners without compromising on academic standard (National Center on Universal Design for Learning, 2017; Scott, McGuire \& Embry, 2002; Rose, 2001). UDL principles emerged from a combination of cognitive neuroscience, environmental design, learning theories and teaching practice (CAST, 2014). UDL principles can be applied to improve students' learning outcomes when it is implemented in the design of learning environment, teaching practices, learning experiences, course design and students' assessment (Alazawei, Serenelli \& Lurdqvist, 2016). The Table 2 presents the three core principles of UDL and how they can be applied into instructional practices based on insights from previous literature.

Table 2.

Universal Design for Learning (UDL) principles and instructional practice

UDL Principles and Instructional Practice

1. Principle of Multiple Means of Representation

- Incorporate assistive technologies such as projectors, slides, power points, Public Address Systems (PAS) etc into instruction: Rose and Meyer (2002; 2005); Rose, Hassenlbring, Stahl and Zabalac (2005); Scott, McGuire and Embry (2002).

- Create a visual representation of concepts using graphics, concept maps, animations and story boards: La, Dyjur and Bair (2018).

- Employ logic, statistics and narrative in concept presentation: CAST (2014), La et al. (2018).

- Use language, symbols and text in instruction: CAST (2014).

2. Principle of Multiple Means of Engagement

- Foster students' collaboration and interaction through group discussion, group presentations, peer tutoring, Socratic dialogue and problem-solving activities: CAST (2014); La et al. (2018).

- Use differential instruction: Alberta Education (2010).

- Incorporate ICTs into instruction: La et al. (2018).

- Provide immediate feedback and rewards on students' assessment: CAST (2014), La et al. (2018).

- Support students to develop self-regulatory and metacognitive reflection skills: CAST (2014), La et al. (2018). 
Table 2 continued

3. Principle of Multiple Actions and Expression

- Use a variety of alternative assessment methods and question types: CAST (2014), La et al. (2018).

- Encourage group dialogue and class presentations: CAST (2014), La et al. (2018).

- Encourage note taking among students: La et al. (2018).

- Incorporate social media as communication tool: La et al. (2018).

- Incorporate activities such as role play and debates into instruction: La et al. (2018).

- Provide feedback on assignments: La et al. (2018).

Gender Responsive Collaborative Learning Strategy (GR-CLS) is therefore an instructional strategy that fuses collaborative learning with gender responsive instructional pedagogy in a single framework that is anchored on the three principles of universal design for learning. The Figure 1 presents the framework for the Gender Responsive Collaborative Learning Strategy (GRCLS) designed and implemented in the study.

\section{GENDER RESPONSIVE COLLABORATIVE LEARNING STRATEGY}

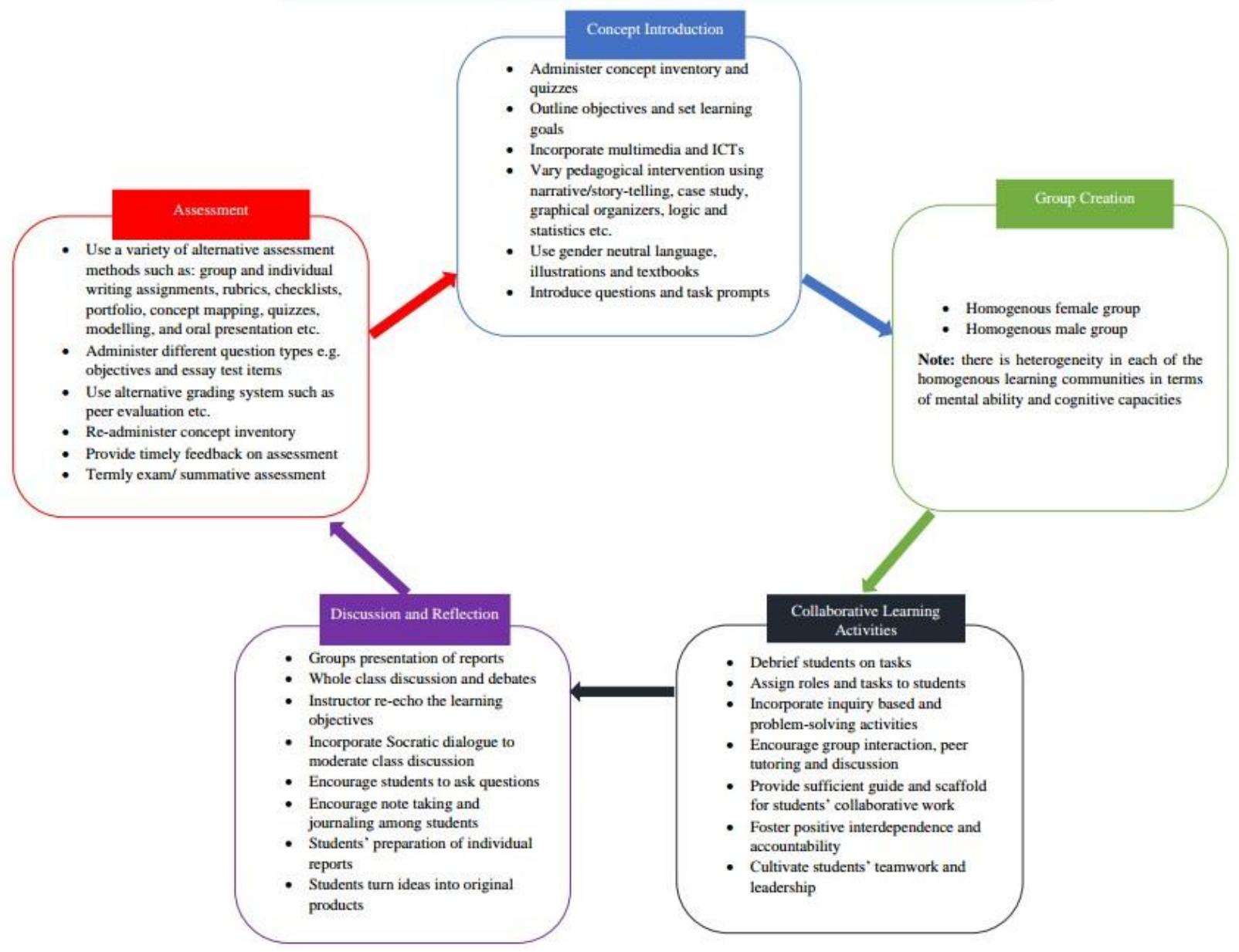

Figure 1. Framework for Gender Responsive Collaborative Learning

\subsection{Research Hypotheses}

The following null hypotheses were formulated:

a. There will be no significant difference in the biology achievement of students who are exposed to GR-CLS and those who are not exposed under virtual and hands-on laboratory learning environment. 
b. There will be no significant difference in the attitudes towards biology of students who are exposed to GR-CLS and those who are not exposed under virtual and hands-on laboratory learning environment.

c. There will be no significant difference in the biology achievement of male and female students taught with GR-CLS under virtual and hands-on laboratory learning modes.

d. There will be no significant difference in the attitudes towards biology of male and female students who are exposed to GR-CLS under virtual and hands-on laboratory learning modes.

e. There will be no significant interaction effect of treatment and school type on students' achievement in biology.

f. There will be no significant interaction effect of treatment and school type on students' attitude towards biology.

\section{Method}

\subsection{Research Design}

The current study integrated a documentary survey with a mixed factorial quasi-experimental research design. A documentary survey research is conducted through the systematic inquiry and the investigation of developments and the experience of the past in other to proffer solution to current challenges (Kerlinger, 1979). The documentary survey of the past literature on gender inclusive pedagogy was applied in the design of the gender responsive collaboratively learning strategy. This research approach provided data that focus on the best practices for promoting gender equality in the science classroom based on how different people construct and conceptualize gender inclusive pedagogies for science teaching and learning. The factorial quasiexperimental design was deemed appropriate for the study because the effects of two or more independent variables on the dependent variables and also how the independent variables interact to effect changes on the dependent variables are investigated. The independent variables, otherwise known as factors, operate at different levels (Rogers \& Revesz, 2020). The $4 \times 2 \times 2$ factorial quasi-experimental design adopted in the study comprised of the treatment manipulated at four levels (see Table 3), and the moderator variables such as gender at two levels (male and females) and school type at two levels (homogenous gender and heterogenous gender). The dependent variables are the achievement and the attitude of students towards biology, respectively. The control group 1 and 2 in Table 3 serve as comparison groups for the experimental group 1 and 2 respectively. This matching approach reveals the mean difference between two or more groups that have the same attributes (Kerlinger, 1979). Thus, controlling for GR-CLS treatment exposed the mean difference in the learning outcomes of students taught with GR-CLS in virtual and hands-on laboratory environments respectively and those who were not taught with the GR-CLS instructional model.

\section{Table 3.}

Research design outline

\begin{tabular}{llll}
\hline Groups & Pre-test & Treatments & Post-test \\
\hline Experimental Group 1 (EG1) & $\mathrm{O}_{1}$ & GR-CLS + VLAB & $\mathrm{O}_{2}$ \\
Experimental Group 2 (EG2) & $\mathrm{O}_{3}$ & GR-CLS + HOL & $\mathrm{O}_{4}$ \\
Control Group 1 (CG1) & $\mathrm{O}_{5}$ & VLAB & $\mathrm{O}_{6}$ \\
Control Group 2 (CG2) & $\mathrm{O}_{7}$ & HOL & $\mathrm{O}_{8}$ \\
\hline
\end{tabular}

GR-CLS- Gender Responsive Collaborative Learning Strategy; VLAB- Virtual Laboratory; HOL- Hands-on Laboratory

\subsection{Sample and Sampling Technique}

A multistage sampling technique was used to select a sample of 218 senior secondary school students from a population of 6,485 senior secondary school students in Ikeja and Lagos mainland local government areas of Lagos State. First, all the public senior secondary schools in the aforementioned local governments were arranged into three different clusters based on gender 
composition which consisted of same sex school (male), same sex school (female) and coeducation/mixed sex school. Second, convenient sampling was used to select two schools that have well equipped computer laboratories, standard biology laboratories and ICT enriched classrooms from each cluster to give a total number of six schools used in the study. Finally, students from intact classes in each of the selected school clusters were randomly assigned to the experimental and control groups respectively. Table 4 highlights the demographic distribution of students in experimental and control groups.

Table 4.

Demographic distribution of sample

\begin{tabular}{cccccc}
\hline \multirow{2}{*}{ Groups } & \multicolumn{3}{c}{ Gender } & \multicolumn{3}{c}{ School Cluster } \\
& Male & Female & Same sex (Male) & Same sex (Female) & Mixed sex \\
\hline EG1 & 36 & 24 & 18 & 12 & 30 \\
EG2 & 22 & 36 & 10 & 14 & 34 \\
CG1 & 22 & 26 & 12 & 18 & 18 \\
CG2 & 28 & 24 & 10 & & 32 \\
\hline Total & 108 & 110 & & 10 & \\
\hline
\end{tabular}

\subsection{Data Collection Tool}

Biology Virtual Laboratory (B-VLAB) instructional package, Biology Achievement Test (BAT) and Attitudes Towards Biology (ATB) questionnaire were utilized as data collection tools. The B-VLAB stimulus instrument was obtained from a large repository of research based virtual laboratory online resources. The B-VLAB package adopted in the study was further subjected to experts and content validation processes by an educational technology expert and two science curriculum specialists in other to ensure its' technical usability and alignment with the Nigerian senior secondary school biology curriculum.

A thirty items BAT was developed by the researchers. The objective test question items of the BAT were adapted from standardized past examination questions administered by the West African Examinations Council (WAEC). Table of specification from the revised Blooms taxonomy (Anderson \& Krathwohl, 2001) was applied in the construction of the test items to ensure adequate coverage of the biology contents that students were exposed to in the virtual and hands-on laboratory learning environments. The following are sample questions from the BAT.

1a. Predict the result of the following protocol. Potato cores with an osmolality of $0.5 \mathrm{M}$ are placed in a 1.0M solution of sucrose water overnight. A. The potato cores will gain mass. B. The potato cores will lose mass. C. The potato cores will neither gain nor lose mass. D. You cannot determine the outcome.

1b. The reason for my answer in number $1 a$ above is because: A. Water moves from a high concentration of water to a low concentration of water through a membrane. B. Water moves from a low concentration of water to a high concentration of water through a membrane. C. Solutes move from a high concentration of solutes to a low concentration of solutes. D. Solutes move from a low concentration of solutes to a high concentration of solutes.

The ATB questionnaire utilized in the study is a sixteen-item instrument that measures students' attitudes towards learning biology under the subscales: interests towards biology lessons (interest), importance of biology for future career (importance), and difficulty of biology lessons (difficulty) respectively. All the items in this five-point Likert response format questionnaire were adapted from Prokop, Tuncer, and Chuda (2007). Item samples from the ATB questionnaire are given below. 
I would like to have biology lessons more often....

I often have difficulties understanding what I have learnt in biology.......

Biology is not important in comparison with other courses......

The BAT and ATB questionnaire instrument were pilot tested on some selected sample which were not part of the study's population. The reliability co-efficient for the BPAT instrument using Kuder-Richardson 20 statistics (KR-20) was .89 while the Cronbach's Alpha reliability co-efficient for the ATB questionnaire was .96. The high reliability indices of the BPAT and ATB questionnaire indicate that the research instruments were reliable and suitable for the study.

\subsection{Procedure}

All student participants and teachers recruited for the study received a two hours training session on how to navigate and conduct experiments using the virtual laboratory resources prior to the commencement of the teaching and learning scenario. In addition, the biology teachers in the experimental groups were exposed to intensive one-week pedagogical trainings on how to implement the gender responsive collaborative learning strategy in the classroom. While the teachers' received pedagogic training, the students on the other hand were administered with the BPAT and ATB questionnaire as pretest and pre attitude instruments respectively, after a short briefing on the objectives of the study and the roles they are expected to play. The pretest and preattitude instruments were administered in other to ascertain the equivalence of the experimental and control group at the beginning of the study's experimental procedure. The random assignment of students to the experimental and control groups (see Table 3) was also achieved in this phase of the study.

The weekly teaching and learning scenario commenced in the second week with the implementation of the GR-CLS learning cycle (see Figure 1 above) in the teaching and learning of the following biology concepts:

- Qualitative test for starch, fats, protein and reducing sugar in food samples.

- The cell and its environment (osmosis and diffusion concepts).

- Influence of light intensity and carbon dioxide on the rate of photosynthesis.

For instance, to implement the GR-CLS in the learning of the cell and its environment concept, students took concept inventories and quizzes prior to the introduction of the biology concept by the teacher. The teacher incorporated assistive technologies and multimedia to enhance students' visualization when introducing the biology concepts. The teacher also ensured that gender neutral language was used in the discursive part of the lesson. Thereafter, students were assigned to homogenous gender collaborative learning groups for class and laboratory activities. At this point, the biology teacher introduced gender specific instructional approach to cater for the need and interests of students in the homogenous female and homogenous male collaborative learning groups respectively. The teacher also provided the necessary scaffold for students' interactions in each of the homogenous gender collaborative learning groups. The entire class re-converged for whole class discussion and presentations of group reports upon the completion of class and laboratory activities. The teacher incorporated Socratic dialogue and questioning to moderate class discussions and to elicit further responses from the students. The students were encouraged to keep a personal reflective journal of class activities and discussion. The students were also encouraged to represent their ideas of the cell and environment concepts using graphical organizers, pictorials and concept maps. The teacher varied the assessment of students on the biology concepts and also ensured the provision of timely feed backs on the performance of the students.

The GR-CLS was implemented with students from the EG1 and EG2 respectively. Students in the EG1 carried out their laboratory activities utilizing the virtual biology laboratory which provided a computer-controlled simulation experiments of the biology concepts whereas students 
in the EG2 were exposed to the regular hands-on laboratory learning environment. Contrarily, the students in the control groups were not exposed to the GR-CLS but rather received their regular biology instruction and thereafter carried out their practical laboratory sessions in heterogenous gender learning groups. Students in the CG1 were exposed to virtual biology laboratory while those in the CG2 conducted experiments in the regular hands-on laboratory. The entire teaching and learning scenario lasted for a duration of ten weeks.

Finally, the reshuffled BAT and ATB questionnaire research instruments were administered as post-test and post-attitude instruments to all the students from the experimental and control groups in the preceding week that marked the end of the teaching and learning scenario. Data accumulated from the pre and post administration of the research instruments were computed in SPSS version 25 and analyzed using descriptive and inferential statistics.

\section{Results}

An independent samples $t$-test was conducted on the pretest and pre-attitude instrument for the experimental and control group. Table 5 shows no significant difference in the mean achievement and attitude scores of the experimental and control group, respectively. Hence, the treatment groups were adjudged to be equivalent at the beginning of the experiment.

Table 5.

Descriptive statistics for the pretest and pre-attitude of the treatment groups

\begin{tabular}{llllll}
\hline & \multicolumn{2}{c}{ Experimental } & \multicolumn{2}{c}{ Control } & \\
Variables & Mean & SD & Mean & SD & t-test \\
\hline Achievement & 9.02 & 2.10 & 9.52 & 1.61 & .052 \\
Attitude & 38.48 & 7.85 & 39.01 & 6.62 & .592 \\
\hline
\end{tabular}

${ }^{*}$ Significant at $\mathrm{p}<.05$

$\mathrm{HO}_{\mathbf{1}}$ : There will be no significant difference in the biology achievement of students who are exposed to GR-CLS and those who are not exposed under virtual and hands-on laboratory environment.

A synthesis of empirical findings from Table 6 reveal that students who are generally exposed to GR-CLS under virtual and hand-on laboratory learning environments recorded higher mean difference (10.09) on achievement scores than their counterparts who are not exposed to GR-CLS (mean difference $=1.13$ ).

Table 6.

Descriptive statistics of pre-test and post-test by treatment

\begin{tabular}{llllll}
\hline & \multicolumn{2}{c}{ Pre-test } & \multicolumn{2}{c}{ Post test } \\
Group(N) & Mean & SD & Mean & SD & Mean diff \\
\hline EG1 (60) & 8.90 & 1.69 & 20.02 & 7.19 & 11.12 \\
EG2 (58) & 9.14 & 2.46 & 18.17 & 6.69 & 9.03 \\
CG1 (48) & 9.38 & 1.72 & 10.75 & 2.07 & 1.37 \\
CG2 (52) & 9.65 & 1.50 & 10.56 & 1.78 & 0.91 \\
\hline Experimental (118) & 9.02 & 2.10 & 19.11 & 6.98 & 10.09 \\
Control (100) & 9.52 & 1.61 & 10.65 & 1.92 & 1.13 \\
\hline
\end{tabular}

Table 7 shows the ANCOVA summary results used to check whether there is a significant difference in the biology achievement of students who were exposed to GR-CLS and those who were not exposed to the treatment. Results indicated that there is a significant main effect of treatment on the biology achievement of students $\left\{F_{(3,201)}=37.813 ; p=.000<.05 ; \eta^{2}=.361\right\}$. The effect size of $36.1 \%$ revealed that treatment had a high impact on the achievement of students. Hence, the null hypothesis was rejected to conclude that treatment had a significant effect on the achievement of students. Table 8 revealed that students who were exposed to GR-CLS in a virtual 
and hands-on laboratory learning environment had the highest estimated marginal means of 19.28 and 18.06 respectively for the post-test when compared to students who were not exposed to the GR-CLS. Students taught with virtual laboratory only recorded an estimated marginal mean of 10.75 which was quite close to those who were introduced to hands-on laboratory only with a mean of 10.60. Furthermore, a pairwise Post-Hoc analysis with Bonferroni corrections showed that the significant main effect of treatment on the achievement of students was due to the significant interaction between: EG1 and CG1 $(p=.000<.05)$, EG1 and CG2 $(p=.000<.05)$, EG2 and CG1 $(p=.000<.05)$, and EG2 and CG2 $(p=.000<.05)$ respectively. However, there was no significant interaction between EG1 and EG2 $(p=1.000>.05)$, and CG1 and CG2 $(p=1.000>.05)$ respectively.

Table 7.

ANCOVA result of students' achievement by treatment

Tests of Between-Subjects Effects

Dependent Variable: POST TEST

\begin{tabular}{lrrrrrc}
\hline Source & $\begin{array}{c}\text { Type III Sum } \\
\text { of Squares }\end{array}$ & Df & \multicolumn{1}{c}{$\begin{array}{c}\text { Mean } \\
\text { Square }\end{array}$} & F & Sig. & $\begin{array}{c}\text { Partial Eta } \\
\text { Squared }\end{array}$ \\
\hline Corrected Model & $4375.128^{\mathrm{a}}$ & 16 & 273.446 & 9.855 & .000 & .440 \\
Intercept & 2017.330 & 1 & 2017.330 & 72.701 & .000 & .266 \\
PRETEST & 16.610 & 1 & 16.610 & .599 & .440 & .003 \\
Treatment (T) & 3147.727 & 3 & 1049.242 & 37.813 & .000 & .361 \\
Gender (G) & 19.406 & 1 & 19.406 & .699 & .404 & .003 \\
School type (S) & .661 & 1 & .661 & .024 & .877 & .000 \\
$\mathrm{~T}^{*} \mathrm{G}$ & 20.233 & 3 & 6.744 & .243 & .866 & .004 \\
$\mathrm{~T}^{*} \mathrm{G}$ & 276.456 & 3 & 92.152 & 3.321 & .021 & .047 \\
$\mathrm{G}^{*} \mathrm{~S}$ & 41.556 & 1 & 41.556 & 1.498 & .222 & .007 \\
$\mathrm{~T}^{*} \mathrm{G}^{*} \mathrm{~S}$ & 93.096 & 3 & 31.032 & 1.118 & .343 & .016 \\
Error & 5577.404 & 201 & 27.748 & & & \\
Total & 60514.000 & 218 & & & & \\
Corrected Total & 9952.532 & 217 & & & & \\
\hline
\end{tabular}

a. $\mathrm{R}$ Squared $=.440$ (Adjusted R Squared $=.395$ )

Table 8.

Estimated marginal mean of posttest by treatment

Dependent Variable: POST TEST

\begin{tabular}{lcrrr}
\hline Treatment & Mean & Std. Error & \multicolumn{2}{c}{$95 \%$ Confidence Interval } \\
& & & Lower Bound & Upper Bound \\
\hline EG1 & $19.281^{\mathrm{a}}$ & .751 & 17.800 & 20.762 \\
EG2 & $18.061^{\mathrm{a}}$ & .715 & 16.652 & 19.470 \\
CG1 & $10.756^{\mathrm{a}}$ & .788 & 9.202 & 12.310 \\
CG2 & $10.601^{\mathrm{a}}$ & .747 & 9.128 & 12.073 \\
\hline
\end{tabular}

a. Covariates appearing in the model are evaluated at the following values: PRE-TEST $=9.25$.

$\mathbf{H 0}_{2}$ : there will be no significant difference in the biology attitude of students who are exposed to GR-CLS and those who are not exposed under virtual and hands-on laboratory learning environment.

The descriptive statistics table 9 for the pre-attitude and post-attitude scores show that students who are exposed to GR-CLS display more positive attitude towards biology (mean difference = 15.55) than those who are not exposed to GR-CLS (mean difference $=2.3$ ). 
Table 9.

Descriptive statistics of pre-attitude and post-attitude by treatment

\begin{tabular}{llllll}
\hline & \multicolumn{2}{c}{ Pre-attitude } & \multicolumn{2}{c}{ Post-attitude } & \\
Group(N) & Mean & SD & Mean & SD & Mean diff \\
\hline EG1 (60) & 38.38 & 7.36 & 55.38 & 8.14 & 17.0 \\
EG2 (58) & 38.59 & 8.39 & 52.62 & 7.88 & 14.03 \\
CG1 (48) & 39.31 & 6.08 & 43.65 & 8.50 & 4.34 \\
CG2 (52) & 38.73 & 7.13 & 39.15 & 10.85 & 0.42 \\
\hline Experimental (118) & 38.48 & 7.85 & 54.03 & 8.10 & 15.55 \\
Control (100) & 39.01 & 6.62 & 41.31 & 10.01 & 2.3 \\
\hline
\end{tabular}

Data from the ANCOVA table 10 show that there is a significant main effect of treatment on the attitude of students towards biology $\left\{F_{(3,201)}=45.118 ; p=.000<.05 ; \eta^{2}=.402\right\}$. The effect size revealed that gender responsive collaborative learning strategy accounted for $40.2 \%$ variance in the attitude of students towards learning biology. Data from the estimated marginal mean table 11 indicated that students who were exposed to GR-CLS under virtual laboratory learning mode recorded that highest post attitude estimated mean value of 55.77 followed closely students exposed to GR-CLR under hands-on laboratory mode with an estimated mean of 52.82. However, students who were taught with virtual laboratory only, had an estimated post attitude mean of 44.14 while those exposed to hands-on laboratory only, recorded the least estimated marginal mean of 38.46. In addition, a Post Hoc pairwise comparison with Bonferroni correction was carried out in other to ascertain the interactions within treatment groups. Statistical findings revealed that the significant main effect of treatment in boosting the attitude of students was due to the interactions between: EG1 and CG1 ( $p=.000<.05)$, EG1 and CG2 $(p=.000<.05)$, EG2 and CG1 $(p=.000<.05)$, EG2 and CG2 $(p=.000<.05)$ and CG1 and CG2 $(p=.007<.05)$ respectively. Nevertheless, there was no significant interaction between EG1 and EG2 ( $p=.449>.05)$.

Table 10.

ANCOVA result of students' attitude by treatment

Tests of Between-Subjects Effects

Dependent Variable: POST ATTITUDE

\begin{tabular}{lrrrrrc}
\hline Source & $\begin{array}{c}\text { Type III Sum } \\
\text { of Squares }\end{array}$ & Df & $\begin{array}{c}\text { Mean } \\
\text { Square }\end{array}$ & F & Sig. & $\begin{array}{c}\text { Partial Eta } \\
\text { Squared }\end{array}$ \\
\hline Corrected Model & $12225.205^{\mathrm{a}}$ & 16 & 764.075 & 10.873 & .000 & .464 \\
Intercept & 14240.501 & 1 & 14240.501 & 202.648 & .000 & .502 \\
PRE-ATTITUDE & 10.667 & 1 & 10.667 & .152 & .697 & .001 \\
Treatment (T) & 9511.579 & 3 & 3170.526 & 45.118 & .000 & .402 \\
Gender (G) & 61.295 & 1 & 61.295 & .872 & .351 & .004 \\
School type (S) & 136.419 & 1 & 136.419 & 1.941 & .165 & .010 \\
$\mathrm{~T}^{*} \mathrm{G}$ & 309.868 & 3 & 103.289 & 1.470 & .224 & .021 \\
$\mathrm{~T}^{*} \mathrm{~S}$ & 669.205 & 3 & 223.068 & 3.174 & .025 & .045 \\
$\mathrm{G}^{*} \mathrm{~S}$ & 775.108 & 1 & 775.108 & 11.030 & .001 & .052 \\
$\mathrm{~T}^{*} \mathrm{G}^{*} \mathrm{~S}$ & 486.894 & 3 & 162.298 & 2.310 & .078 & .033 \\
Error & 14124.703 & 201 & 70.272 & & & \\
Total & 532662.000 & 218 & & & & \\
Corrected Total & 26349.908 & 217 & & & & \\
\hline a & $217 q$. & & & &
\end{tabular}

a. R Squared $=.464$ (Adjusted R Squared $=.421$ ) 
Table 11.

Estimated marginal mean of post-attitude by treatment

Estimates

Dependent Variable: POST ATTITUDE

\begin{tabular}{lccrr}
\hline Treatment & Mean & Std. Error & \multicolumn{2}{c}{$95 \%$ Confidence Interval } \\
& & & Lower Bound & Upper Bound \\
\hline EG1 & $55.770^{\mathrm{a}}$ & 1.189 & 53.425 & 58.116 \\
EG2 & $52.821^{\mathrm{a}}$ & 1.138 & 50.576 & 55.066 \\
CG1 & $44.142^{\mathrm{a}}$ & 1.255 & 41.667 & 46.617 \\
CG2 & $38.461^{\mathrm{a}}$ & 1.181 & 36.132 & 40.791 \\
\hline
\end{tabular}

a. Covariates appearing in the model are evaluated at the following values: PRE-ATTITUDE $=38.72$.

$\mathrm{HO}_{3}$ : there will be no significant difference in the achievement of male and female students taught with GR-CLS under virtual and hands-on laboratory learning modes.

Table 12 show that GR-CLS generally improved the achievement of both male and female students who recorded higher mean gains compared to male and female students who were not exposed to the treatment. Female students who were exposed to GR-CLS recorded higher mean difference (10.45) than their male counterparts (mean difference= 9.72), thus suggesting that GR-CLS favour the achievement of females more than males. However, the male students in the control group had higher mean difference (1.26) than their female counterparts (mean difference=1.0). Notwithstanding, empirical data from table 7 show that there is no significant difference in achievement of male and female students $\left\{\mathrm{F}_{(1,201)}=.699 ; \mathrm{p}=.404>.05 ; \eta 2=.003\right\}$, neither is there any significant interaction between treatment and gender on the achievement of students $\left\{\mathrm{F}_{(3,201)}\right.$ $=.243 ; \mathrm{p}=.866>.05 ; \eta 2=.004\}$. These results indicate that GR-CLS in the current study closes the achievement gap between male and female students.

Table 12.

Descriptive statistics for mean achievement scores by treatment and gender

\begin{tabular}{llllllc}
\hline & & \multicolumn{2}{c}{ Pre-test } & \multicolumn{2}{c}{ Post test } \\
Group(N) & Gender & Mean & SD & Mean & SD & Mean diff \\
\hline $\operatorname{Exp}(118)$ & male & 9.47 & 2.50 & 19.19 & 6.87 & 9.72 \\
& female & 8.58 & 1.55 & 19.03 & 7.15 & 10.45 \\
Con $(100)$ & male & 9.72 & 1.66 & 10.98 & 2.39 & 1.26 \\
& female & 9.32 & 1.54 & 10.32 & 1.23 & 1.0 \\
\hline
\end{tabular}

$\mathrm{H0}_{4}$ : There will be no significant difference in the attitude of male and female students who are exposed to GR-CLS under virtual and hands-on laboratory learning modes.

It can be inferred from Table 13 that GR-CLS generally improved the attitude of both male and female students towards biology when compared to male and female students from the control groups. Nevertheless, GR-CLS favour the male students (mean difference=16.31) more than the females (mean difference=14.80). Consequently, male students who were not exposed to GR-CLS recorded higher mean difference (4.28) than the female students (mean difference $=0.32$ ) who were not exposed to GR-CLS. Notwithstanding, table 10 revealed that there was no significant main effect of gender $\left\{F_{(1,201)}=.872 ; p=.351>.05 ; \eta^{2}=.004\right\}$, and interaction effect between treatment and gender $\left\{F_{(3,201)}=1.470 ; p=.224>.05 ; \eta^{2}=.021\right\}$ on the attitude of students respectively. 
Table 13.

Descriptive statistics for mean attitude measure by treatment and gender

\begin{tabular}{lllllll}
\hline & \multicolumn{2}{c}{ Pre-attitude } & \multicolumn{2}{c}{ Post attitude } \\
Group $(\mathrm{N})$ & Gender & Mean & SD & Mean & SD & Mean diff \\
\hline Exp (118) & male & 38.31 & 8.42 & 54.62 & 8.10 & 16.31 \\
& female & 38.65 & 7.33 & 53.45 & 8.12 & 14.80 \\
Con $(100)$ & male & 38.82 & 6.78 & 43.10 & 8.41 & 4.28 \\
& female & 39.20 & 6.52 & 39.52 & 11.18 & 0.32 \\
\hline
\end{tabular}

H05: there will be no significant interaction effect of treatment and school type on students' achievement in biology.

The descriptive statistics Table 14 revealed that GR-CLS improved the academic achievement of students irrespective of their school type. Nonetheless, this instructional paradigm favour homogenous school type (mean difference $=10.7$ ) over heterogenous school type (mean difference =9.58). Furthermore, students who were not exposed to the GR-CLS recorded lesser mean difference of 1.26 and 1.0 for the homogenous and heterogenous school types respectively. The ANCOVA Table (i.e., Table 7) revealed non-significant main effect of school type on student achievement $\left\{F_{(1,201)}=.024 ; p=.877>.05 ; \eta^{2}=.000\right.$. There was however a significant interaction between treatment and school type $\left\{F_{(3,201)}=.3 .321 ; p=.021<.05 ; \eta^{2}=.047\right\}$, also see the graph 1 . The effect size of $4.7 \%$ show that GR-CLS significantly improved the achievement of students from same sex schools more than those from mixed sex schools. Notwithstanding, there was no significant interaction between gender and school type $\left\{F_{(1,201)}=1.498 ; p=.222>.05 ; \eta^{2}=.007\right\}$, treatment, gender and school type $\left\{F_{3,201)}=1.118 ; p=.343>.05 ; \eta^{2}=.016\right\}$ respectively.

Table 14.

Descriptive statistics of mean achievement scores based on treatment and school type

\begin{tabular}{lcclccc}
\hline & & \multicolumn{2}{c}{ Pre-test } & \multicolumn{2}{c}{ Post test } & \multicolumn{2}{c}{ Mean } \\
Group(N) & School type(N) & Mean & SD & Mean & SD & diff \\
\hline Exp (118) & homogenous(54) & 8.80 & 1.63 & 19.50 & 7.39 & 10.7 \\
& heterogenous(64) & 9.20 & 2.42 & 18.78 & 6.66 & 9.58 \\
Con (100) & homogenous(50) & 9.50 & 1.70 & 10.76 & 2.19 & 1.26 \\
& heterogenous(50) & 9.54 & 1.52 & 10.54 & 1.63 & 1.0 \\
\hline
\end{tabular}

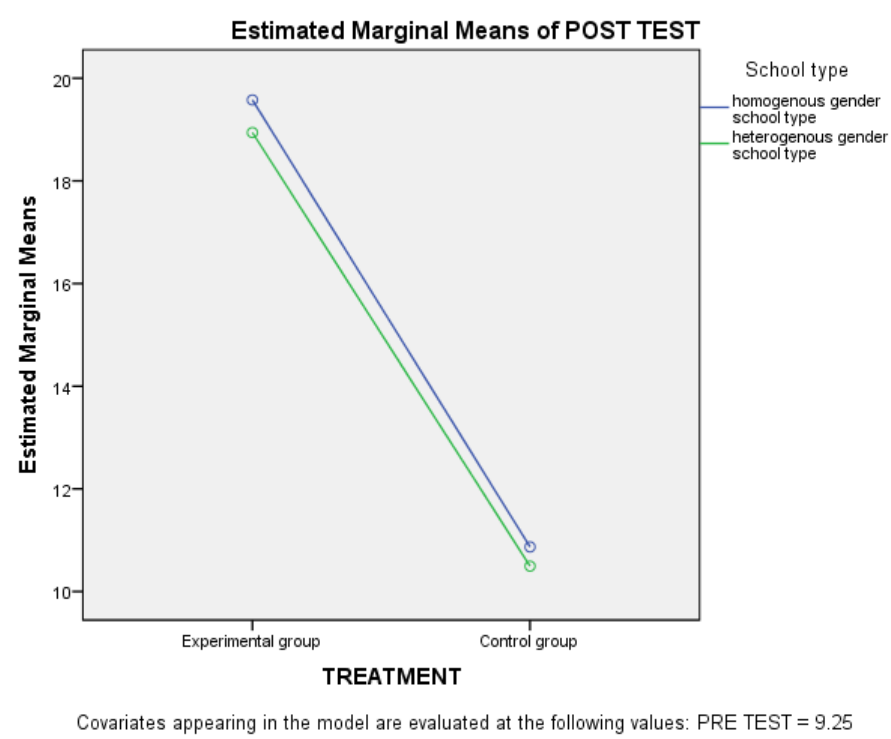

Graph 1. Interaction of treatment and school type on achievement 


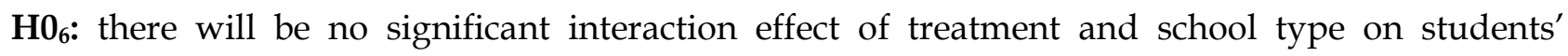
attitude towards biology.

Table 15 which shows the descriptive statistics for the attitude of students based on school type indicates that GR-CLS bolsters the attitude of students from homogenous gender school type (mean difference $=20.39$ ) more than their counterparts from heterogenous gender school type (mean difference $=11.46$ ). Students who were not exposed to the GR-CLS had the least mean gains of 2.06 and 2.54 for homogenous and heterogenous gender school types respectively. The results of the ANCOVA Table 10 revealed that there was no significant main effect of school type on students' attitude $\left\{F_{(1,201)}=1.941 ; p=.165>.05 ; \eta^{2}=.010\right\}$. There was also no significant interaction between treatment, gender and school type $\left\{F_{(3,201)}=2.310 ; p=.078>.05 ; \eta^{2}=.033\right\}$. There was however a significant interaction between treatment and school type $\left\{F_{(3,201)}=3.174 ; p=.025<.05\right.$; $\left.\eta^{2}=.045\right\}$. Graph 2 indicated that GR-CLS significantly improved the attitude of students from same sex schools more than their counterparts from mixed sex schools.

Table 15.

Descriptive statistics of students' attitude measure based on treatment and school type

\begin{tabular}{lccllll}
\hline & & \multicolumn{2}{c}{ Pre-attitude } & \multicolumn{2}{c}{ Post attitude } & \multicolumn{2}{l}{ Mean } \\
Group(N) & School type(N) & Mean & SD & Mean & SD & diff \\
\hline Exp (118) & homogenous(54) & 35.39 & 9.80 & 55.78 & 8.17 & 20.39 \\
& heterogenous(64) & 41.09 & 4.30 & 52.55 & 7.80 & 11.46 \\
Con (100) & homogenous(50) & 39.08 & 6.67 & 41.14 & 10.60 & 2.06 \\
& heterogenous(50) & 38.94 & 6.64 & 41.48 & 9.47 & 2.54 \\
\hline
\end{tabular}

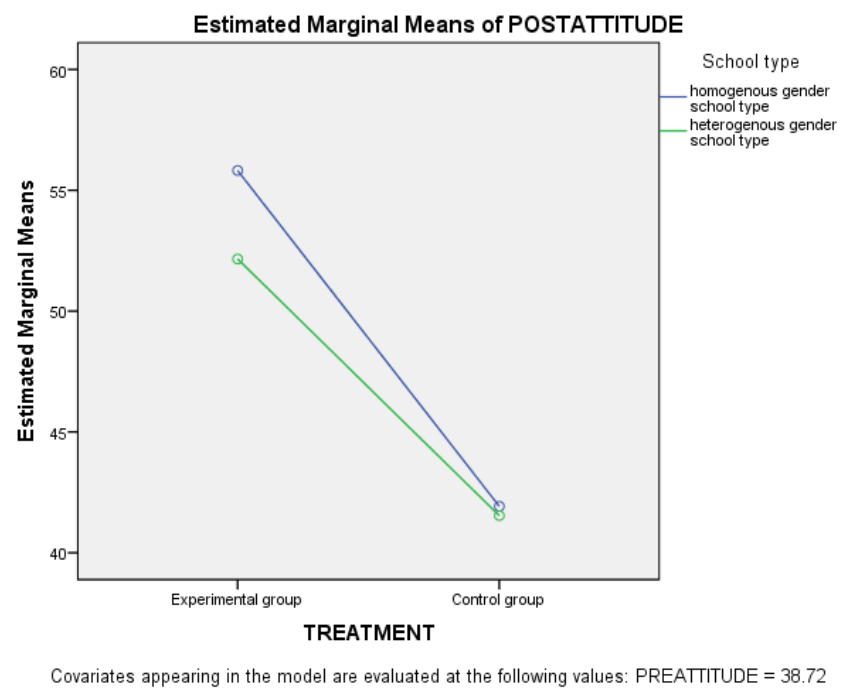

Graph 2. Interaction of treatment and school type on attitude

\section{Discussion}

The researchers in this study designed and implemented GR-CLS under virtual and hands-on laboratory learning environment. Empirical findings from the study revealed that gender responsive collaborative model for science instruction statistically significantly improved the academic achievement and attitude of students towards learning in a virtual and hands-on laboratory learning environment respectively. This may be due to the high level of significant interactions between the experimental groups exposed to GR-CLS and the control who were not exposed to GR-CLS. Besides, the post hoc analysis also revealed no significant interaction between the EG1 and EG2 treatments. These findings show that the significant improvements in the learning outcomes of students were due to the overarching effectiveness of the GR-CLS. Students who were exposed to GR-CLS under virtual and hand-on laboratory learning environments 
recorded a high and significant improvement in their achievement and attitude compared to those who were not exposed to GR-CLS. This is because the GR-CLS designed and implemented in the study offered gender specific instruction to students in a collaborative learning setting. These findings support the view that gender sensitive classroom interaction pattern is an effective pedagogical strategy for improving the performance of both male and female students (Dickey, 2014; Stotksy, 2012). Besides, the characteristic feature of the GR-CLS which involves the homogenous grouping of students by gender in the collaborative learning environment also align with the position of previous studies where homogenous gender collaborative learning setting was adjudged to be more effective than heterogenous gender learning groups (Bennett el at. 2010; Gambari et al., 2018; Tsai, 2012). The findings from the study, however, did not agree with the submission of Baker (2002) that the heterogenous grouping of students by gender in collaborative learning environments favour learning improvements compared to homogenous gender grouping.

Furthermore, findings from the study revealed that students who were taught in virtual laboratory learning environment (CG1) recorded a higher mean achievement scores compared to students who were taught in the conventional hands-on laboratory (CG2). Nevertheless, the post hoc pairwise comparison revealed that there was no significant difference between these groups. The closeness in the estimated marginal means of the CG1 and CG2 suggests virtual laboratory to be effective as the conventional hands-on laboratory. This is because virtual laboratory aids students' visualization and formation of mental models of the phenomena being studied in the virtual learning environment (Mayer, 1999a; 1999b; Zacharia, 2015). In another dimension, there was a significant difference in the attitude of students taught in virtual laboratory and hands-on laboratory learning environments. This finding indicates that virtual laboratory significantly improved the attitude of students towards biology. The above finding on the effectiveness of virtual laboratory on students' achievement is supported by Darrah et al. (2014), Pyatt and Sims (2012), Zacharia and Olympiou (2011), Mcqueen (2017), Talti and Ayas (2012) who documented separate findings that equate the effectiveness of virtual laboratory to the physical laboratory. In addition, Gambari et al. (2014) reported that virtual laboratory has a significant and positive effect on the attitude of students. Likewise, Tüysüz (2010) posited that high school students who are exposed to virtual laboratory showed great improvements in their attitude. Notwithstanding, findings from the study did not agree with Ambusaidi et al. (2017) who reported that ninth grade science students in hands-on laboratory learning environment significantly outperformed their counterparts who were exposed to virtual chemistry laboratory. Similarly, the study findings did not agree with Oser (2013) who reported that virtual laboratory did not have any significant impact on the attitude of high school students towards science.

Empirical findings from the current study revealed that the gender responsive collaborative model for science instruction designed in the study flattened the curve and gaps in the achievement and attitude of male and female students respectively. Data gleaned from the study indicate that GR-CLS bolsters the academic achievement of female students more than the male students. This is because GR-CLS provided avenue for female-female interactions and active participation in laboratory activities thereby eliminating the bias of male dominated collaborative learning groups during science activities. The non-significant differences in achievement of male and female students, and in the interaction between treatment and gender give credence to this assertion. This pedagogical practice, as corroborated by Chadwell (2010), provided the opportunities for female students to interact with each other, ask questions and clarify their thoughts which, in turn, resulted in an improvement in their achievement. Similarly, it was also discovered that the gender responsive instructional paradigm implemented in the study resulted in an improvement in the attitude of male and female students. The male students, however, had more positive attitude towards learning than their female counterparts. Notwithstanding, there was no significant main effect of gender, and interaction effect between treatment and gender on the attitude of students respectively. These results implied that GR-CLS fostered students' high academic achievement and positive attitude towards science regardless of their gender. These 
findings agreed with the position that gender equality in science education can be achieved if gender components are mainstreamed into science classroom activities and interactions (UNESCO, 2017). Furthermore, findings from the study aligned with Gambari et al. (2013) and Gambari (2010) whose separate reports affirmed that gender do not influence the academic performance of students in virtual learning environments. Contrariwise, the study did not agree with the findings of Oser (2013) and Kost, Pollock, Finkelsten (2009) where gender was reported to influence the performance of students in interactive learning environments in favour of the male students.

As a final remark, it can also be inferred from the study that GR-CLS improved the achievement and attitude of students from both homogenous and heterogenous gender school types. Notwithstanding, it was discovered that the effect of this instructional strategy on students' achievement favour homogenous gender school type more than heterogenous gender school type. Furthermore, the significant interaction between treatment and school type on students' achievement indicates that GR-CLS significantly improved the academic achievement of students from same sex schools over those from mixed sex schools. Likewise, empirical data from the study revealed that the effect of gender responsive instructional paradigm on students' attitude favoured homogenous gender school type more than the heterogenous gender school type. The mean difference between the two group was also statistically significant.

\section{Conclusion}

One way of ensuring gender equality in science education is by mainstreaming gender components into the pedagogical delivery of science instruction. It is evident that GR-CLS designed and implemented in the study significantly improved the attitude and academic achievement of students regardless of their gender and school type. The homogenous gender group interactions fostered in the gender responsive collaborative learning environment create opportunities for both male and female students to benefit maximally from science learning activities. In addition, empirical data from the study reaffirms the efficacy of virtual laboratory as an effective pedagogical tool for improving the achievement of students in science.

\subsection{Recommendations and Suggestions for Future Research}

The following recommendations are made based on the findings of the study:

a. Science teachers who aspire to create a gender inclusive learning environment should adopt the gender responsive collaborative learning instructional model designed and implemented in the study.

b. Preservice and in-service science teachers should be exposed to pedagogic trainings and professional development course that focus on how to design and implement science lessons that incorporate gender responsive pedagogies. Furthermore, insights from science teachers' community of practice on the implementation of the GR-CLS should be incorporated in the refinement of our gender responsive collaborative learning model.

c. Virtual laboratory should be adopted by science teachers as an alternative to hands-on laboratory because empirical evidence from the study revealed that virtual laboratory is as effective as the conventional physical laboratory.

d. The study should be replicated within the domains of other science subjects such as chemistry and physics, and with a larger and more culturally diverse sample. Besides, further studies should incorporate mixed methodological approaches to gathering data on students learning outcomes after exposure to gender responsive pedagogies. 


\section{References}

Adegoke, B.A., \& Chukwunenye, N. (2013). Improving students' learning outcomes in practical physics, which is better? computer simulated experiment or hands-on experiment? IOSR Journal of Research $\mathcal{E}$ Method in Education (IOSR-JRME), 2(6), 18-26.

Adejoh, M. J., \& Ityokyaa, F. M. (2009). Availability and adequacy of laboratory and workshop resources in secondary schools in Benue State, Nigeria. Journal of Research in Curriculum and Teaching, 4(1), 304-311.

Akpan, J., \& Strayer, J. (2010). Which comes first: The use of computer simulation for frog dissection or conventional dissection as an academic exercise? Journal of Computers in Mathematics and Science Teaching, 29, 113-138.

Al-Azawei, A., Serenelli, F., \& Lundqvist, K. (2016). Universal design for learning (UDL): A content analysis of peer-reviewed journal papers from 2012 to 2015. Journal of the Scholarship of Teaching and Learning, 16(3), 39-56.

Alberta Education (2010). Making a difference: Meeting diverse learning needs with differentiated instruction. Available online at http://education.alberta.ca/media/1234045/makingadifferen ce_2010.pdf

Ambusaidi, A., Al-Musawi, A., Al-Balushi, S., \& Al-Balushi, K. (2017). The impact of virtual lab learning experiences on 9th grade students' achievement and their attitudes towards science and learning by virtual lab. Journal of Turkish Science Education, 15(2), 13-29.

Anderson, L.W., \& Krathwohl, D.V.R. (2001). A taxonomy for learning, teaching and assessing: A revision of Bloom's Taxonomy of educational objectives. Complete edition. New York, NY: Longman.

Andre, J.T.H. (2011). Overcoming gender barriers in science: Facts and figures. Sci Dev Net. Available online at http://www.scidev.net/global/education/feature/overcoming-gender-barriers-in-science-facts-andfigures-1

Astin, A. (1985). Achieving educational excellence. San Francisco, Jossey Bass.

Babateen, H. (2011). The role of virtual laboratories in science education. 5th international conference on distance learning and education. IACSIT Press, Singapore.

Bajpai, M., \& Kumar, A. (2015). Effect of virtual laboratory on students' conceptual achievement in physics. International Journal of Current Research, 7(2), 12808-12813.

Baker, D. (2002). Good intentions: An experiment in middle school single-sex science and mathematics classrooms with high minority enrolment. Journal of Women and Minorities in Science and Engineering, 8, 123.

Baker, D. (2013). What Works: Using curriculum and pedagogy to increase girls' interest and participation in science. Theory into Practice, 52, 14-20. https:// doi/10.1080/07351690.2013.743760

Bennett, J., Hogarth, S., Lubben, F., Campbell, B., \& Robinson, A. (2010). Talking science: The research evidence on the use of small group discussion in science teaching. International Journal of Science Education, 32, 69-95.

Bonwell, C. C., \& Eison, J. A. (1991). Active Learning: Creating Excitement in the Classroom. 1991 ASHE-ERIC Higher Education Reports. The George Washington University: ERIC Clearinghouse on Higher Education.

Bortnik, B., Stozhko, N., Pervukhina, I., Tchernysheva, A., \& Belysheva, G. (2017). Effect of virtual analytic chemistry laboratory on enhancing students' research skills and practices. Research in Learning Technology, 25, 1968. https://doi.org/10.25304/rlt.v25.1968

Brinson, J. R. (2015). Learning outcome achievement in non-traditional (virtual and remote) versus traditional (hands-on) laboratories: A review of the empirical research. Computers $\mathcal{E}$ Education, 38(3), 218237. https://doi:10.1016/j.compedu.2015.07.003

Brown, J. S., Collins, A., \& Duguid, P. (1989). Situated cognition and the culture of learning. Educational Researcher, 18(1), 32-42.

Burman, D.D., Bitan, T., \& Booth, J.R. (2008). Sex differences in neural processing of language among children. Neuro psychologia, 46(5), 349-1362.

Center for Applied Special Technology (CAST) Inc. (2014). The UDL guidelines. Retrieved from http://udlguidelines.cast.org/

Cerbin, B. (2010). Collaborative learning techniques: A handbook for college faculty. Wisconsin: Jossy Bass Publisher.

Chadwell, D. (2010). A gendered choice. Corwin Press, California.

Darrah, M., Humbert, R., Finstein, J., Simon, M., \& Hopkins, J. (2014). Are virtual labs as effective as handson labs for undergraduate physics? A comparative study at two major universities. Journal of Science Education and Technology, 23(6), 803-814.

Deutsch, M. (1976). A theory of cooperation and competition. Human Relations. San Francisco: Jossey-Bass. 
Dickey, M. W. (2014). Gender specific instructional strategies and student achievement in 5th grade classrooms (Doctoral dissertation, University of South Carolina, Columbia). Retrieved from https://scholarcommons.sc.edu/etd/2624

Ekine, A. (2013). Enhancing girls' participation in science in Nigeria. Improving Learning Opportunities and Outcomes for Girls in Africa, 41(3), 12-26.

Elgar, A.G. (2004). Science textbooks for lower secondary schools in Brunei: Issues of gender equity. International Journal of Science Education, 26(7), 875-894.

Gabelnick, F., MacGregor, J., Matthews, R., \& Smith, B.L. (1990). Learning communities: Creating connections among students, Faculty and Disciplines. New Directions for Teaching and Learning. San Francisco: Jossey Bass.

Gambari, I. A. (2010). Effect of computer-supported cooperative learning strategies on the performance of senior secondary students in physics, in Minna, Nigeria. Unpublished PhD dissertation, University of Ilorin, Ilorin, Nigeria.

Gambari, A. I. \& Yusuf, M. O. (2014). Attitude of Nigerian secondary school students towards cooperative learning strategies. Delsu Journal of Educational Research and Development, 12(1), 100 - 131.

Gambari, A. I., Falode, O. C., Fagbemi, P. O., \& Idris, B. (2013). Efficacy of virtual laboratory on the achievement and attitude of secondary school students in physics practical. Journal of Research in Curriculum, 9(1), 9-20.

Gambari, A. I., Kawu, H., \& Falode, O.C. (2018). Impact of virtual laboratory on the achievement of secondary school chemistry students in homogeneous and heterogeneous collaborative environments. Contemporary Educational Technology, 9(3), 246-263. https://doi.org/10.30935/cet.444108

Gambari, A. I., Obielodan, O.O., \& Kawu, H. (2017). Effects of virtual laboratory on achievement levels and gender of secondary school chemistry students in individualized and collaborative settings in Minna, Nigeria. The Online Journal of New Horizons in Education, 7(1), 86-102.

Gurian, M., Stevens, K., \& Daniels, P. (2009). Single-sex classrooms are succeeding. Educational Horizons, 87(4), 234-245.

Haussler, P., \& Hoffman, L. (2002). An intervention study to enhance girls' interest, self-concept, and achievement in physics. Journal of Research in Science Teaching, 39, 870-888.

Herga, N.R, Čagran, $\quad$ B., \& Dinevski, D. (2016). Virtual laboratory in the role of dynamic visualisation for better understanding of chemistry in primary school. Eurasia Journal of Mathematics, Science \& Technology Education, 12(3), 593-608.

Hofstein, A., \& Kind, P. M. (2012). Learning in and from science laboratories. In B. J. Fraser, K. Tobin \& C. McRobbie (Eds.), Second international handbook of science education (pp. 189-207). New York: Springer.

Hubbard, L., \& Datnow, A. (2005). Do single-sex schools improve the education of low-income and minority students? An investigation of California's public single-gender academies. Anthropology and Education Quarterly, 36(2), 115-13.

Kahle, J., \& Meece, J. (1994). Research on gender issues in the classroom. In D. L. Gabel (Ed.), Handbook on Research in Science Teaching and Learning (pp. 542-557). New York, NY: McMillan.

Kerlinger, F.N. (1979). Behavioural research: A conceptual approach. New York: Holt, Reinhart and Wiston.

Kost, L. E., Pollock, S. J., \& Finkelstein, N. D. (2009). Characterizing the gender gap in introductory Physics. Physics Education Research, 5(1), 1-14.

La, H., Dyjur, P., \& Bair, H. (2018). Universal design for learning in higher education. Taylor Institute for Teaching and Learning. Calgary: University of Calgary.

Lewin, K. (1935). A Dynamic Theory of Personality. New York, McGraw Hill.

MacGregor, J. (1990). Collaborative learning: Shared inquiry as a process of reform. In M. Svinicki, (Ed.) The changing face of college teaching. New Directions for Teaching and Learning, 42, 19-30.

MacKinnon, P. (2000). Improving girls' self-esteem: The role of the teacher. An Action Research Project (Pilot Study), Girls Education Unit Research Report. Ghana: UNICEF.

Martino, W. \& Kehler, M. (2007). Gender-based literacy reform: A question of challenging or recuperating gender binaries. Canadian Journal of Education, 30(2), 406-431.

Mayer, R. E. (1999a). Multimedia aids to problem-solving transfer. International Journal of Educational Research, 31(7), 611-623.

Mayer, R. E. (1999b). Research-based principles for the design of instructional messages. Document Design, $1(1), 7-20$.

Mcqueen, J.A. (2017). The effects of biology lab delivery mode on academic achievement in college biology. Unpiublished doctoral dissertation. Texas A\&M University, Corpus Christi, Texas.

Miske, S.J. (2013). Gendered dimensions of teaching and learning. UNGEI: New York. 
Mulholland, J., Hansen, P., \& Kaminski, E. (2004). Do single-gender classrooms in coeducational settings address boys' underachievement? An Australian study. Educational Studies, 30(1), 19-32.

National Center on Universal Design for Learning. (2017). Universal Design for Learning Guidelines. Retrieved from https:// www.udlcenter.org/aboutudl/udlguidelines_theorypractice

Nhundu, T.J. (2007). Mitigating gender-typed occupational preferences of Zimbabwean primary school children: The use of biographical sketches and portrayals of female role models. Sex Roles, 9(56), 639-649.

Olorundare, A. S. (2014). Constructivism and learning in science. 38th Inaugural Lecture Series, University of Ilorin, Nigeria.

Olsen, J., \& Gross, S. (2013). To attract girls to STEM, bring more storytelling to science. Scientific American. Available online at http://blogs.scientificamerican.com/budding-scientist/2013/04/16/to-attract-moregirls-to-stembring-storytelling-to-science/

Omilani N.A., Ochanya N.M.R., \& Aminu S.A. (2018). The effect of combined virtual and real laboratories on students' achievement in practical chemistry. International Journal of Secondary Education, 4(3), 27-31. https://doi:10.11648/j.ijsedu.20160403.11

Oser, R.O. (2013). Effectiveness of virtual laboratories in terms of achievement, attitudes, and learning environment among high school science students. Unpublished doctoral dissertation. Science and Mathematics Education Centre, Curtin University.

Parker, L. L., \& Loudon, G. M. (2012). Case study using online homework in undergraduate organic chemistry: Results and student attitudes. Journal of Chemical Education, 90(1), 37-44.

Parker, L., \& Rennie, L. (2002). Teachers' implementation of gender-inclusive instructional strategies in single-sex and mixed-sex science classrooms. International Journal of Science Education, 24, 881-897.

Polcuch, E. F. (2016, April). SAGA: Facing the challenges in measurement and policies for gender equaility in STEM. Paper presented at Participation of women and girls in STEM education, Mexico City.

Prokop, P., Tuncer, G., \& Chuda, J. (2007). Slovakian students' attitudes toward biology. Eurasia Journal of Mathematics, Science \& Technology Education, 3(4), 287-295.

Pyatt, K., \& Sims, R. (2012). Virtual and physical experimentation in inquiry-based science labs: Attitudes, performance and access. Journal of Science Education and Technology, 21(1), 133-147.

Rajendran, L., Veilumuthu, R., \& Divya, J. (2010). A study on the effectiveness of virtual lab in E-learning. International Journal on Computer Science and Engineering, 2 (6), 2173-2175.

Rogers, J, \& Revesz, A. (2020). Experimental and quasi experimental designs. In J. McKinley \& H. Rose (Eds.), The Routledge handbook of research methods in applied linguistics. New York: Routledge.

Rose, D. H. (2001). Universal design for learning: Deriving guiding principles for networks that learn. Journal of Special Education Technology, 16(2), 66.

Rose, D.H., Hasselbring, T.S., Stahl, S., \& Zabala, J. (2005). Assistive technology and universal design for learning: Two sides of the same coin. In D. Edyburn, K. Higgins, \& R. Boone (Eds.), Handbook of Special Education Technology Research and Practice, 507-518. Whitefish Bay, WI: Knowledge by Design.

Rose, D., \& Meyer, A. (2002). Teaching every student in the digital age. Alexandria, VA: ASCD. Available online at http://www.cast.org/teachingeverystudent/ideas/tes/

Scantlebury, K. \& Baker, D. (2007). Gender issues in science education research: Remembering where the difference lies. In handbook of Research on Science Education, Eds. Sandra K. Abell., \& Norman G. Lederman. Mahwah, NJ: Lawrence Erlbaum Associates, 257-286.

Scott, S., McGuire, J.M., \& Embry, P. (2002). Universal design for instruction fact sheet. Storrs: University of Connecticut, Centre on Postsecondary Education and Disability.

Sempala, F. (2005). Gender differences in performance of chemistry practical skills among chemistry senior six students in Kampala District. Dissertation.com.

Shi, W., He, X., Wang, Y., \& Huan, W. (2015). Effects of lab group sex composition on physics learning. Eurasia Journal of Mathematics, Science \& Technology Education, 11(1), 8792.

Smith, B.L., \& MacGregor, J. (1992). Collaborative learning: A sourcebook for higher education. University Park, PA: National Centre on Postsecondary Teaching, Learning, and Assessment.

Stotsky, S. (2012). The promise of single-sex classes. School Administrator, 69(5), 33-35.

Tatli, Z., \& Ayas, A. (2012). Virtual chemistry laboratory: Effect of constructivist learning environment. Turkish Online Journal of Distance Education, 13(1), 183-199.

Toth, E. E. (2016). Analyzing "real-world" anomalous data after experimentation with a virtual laboratory. Educational Technology Research and Development, 64(1), 157-173.

Tsai, C. (2012). Peer effects on academic cheating among high school students in Taiwan. Asia Pacific Education Review, 13(1), 147-155. 
Tüysüz, C. (2010). The effect of the virtual laboratory on students' achievement and attitude in chemistry. International Online Journal of Educational Sciences, 2(1), 37-53.

Udeani, U.N. (2012). Increasing female participation in science and technology careers: Problems and suggested interventions for Nigeria. Developing Countries Studies, 2(14), 87-94.

UNESCO (2012). Education for All (EFA) global monitoring report. Available online at https://unesdoc.unesco.org/ark:/48223/pf0000218569

UNESCO Report (2017). Cracking the code: Girls and women education in Science, Technology, Engineering and Mathematics (STEM). Available online at https://en.unesco.org/news/new-unesco-report-sheds-lightgender-inequality-stem-education

USAID Report (2015). Gender equality in Science, Technology, Engineering, Agricultural Sciences and Mathematics (STEAM) academic pipeline: Challenges transferring knowledge to practice. Available online at https://www.usaid.gov/sites/default/files/USAID-Report-Sep-2015-Final.pdf

Vasiliou, A. \& Economides, A. A. (2007). Mobile collaborative learning using multicast MANETs. International Journal of Mobile Communications, 5(4), 423-444

West African Examinations Council [WAEC] (2015). WAEC Chief examiners' report Lagos. Lagos: WAEC Press.

Wang, T., Eccles, J.S., \& Kenny, S. (2013). Not lack of ability but more choice: Individual and gender differences in choice of careers in Science, Technology, Engineering, and Mathematics. Psychological Science, 5(24), 770-775.

Zacharia, Z. C. (2015). Examining whether touch sensory feedback is necessary for science learning through experimentation: A literature review of two different lines of research across K-16. Educational Research Review, 16, 116-137.

Zacharia, Z. C., \& Olympiou, G. (2011). Physical versus virtual manipulative experimentation in physics learning. Learning and Instruction, 21(3), 317-331. 